\title{
Analysis of insulin receptors on human lymphoblastoid cell lines by flow cytometry
}

\author{
R. Maron', S.I.Taylor', R. Jackson' and C. R. Kahn' \\ ${ }^{1}$ Research Division, Joslin Diabetes Center, Boston, Massachusetts and \\ ${ }^{2}$ Diabetes Branch, NIADDK, National Institutes of Health, Bethesda, Maryland, USA
}

\begin{abstract}
Summary. Antibodies to the insulin receptor have provided important experimental probes of receptor structure and function. In the present study, we have characterized the insulin receptor on human lymphoblastoid cell lines using polyclonal and monoclonal anti-receptor antibodies and fluorescence flow cytometry. The cell lines were derived by Epstein-Barr virus transformation of peripheral mononuclear leucocytes from normal subjects or patients with disorders that affect the insulin receptor. Fluorescence analysis revealed a high level of specific fluorescence on lymphoid cell lines from normal individuals (mean peak fluorescence 30-50 units above the control) and was similar to the labelling of the spontaneously transformed lymphoblastoid cell line IM-9. Transformed cells
\end{abstract}

from patients with syndromes of insulin resistance, such as the Rabson Mendenhall syndrome, leprechaunism and the type A syndrome of insulin resistance and acanthosis nigricans, exhibited little or no specific fluorescence. In all cases, there was a unimodal distribution of receptors on cells. In addition, there was a good correlation between specific binding of ${ }^{125} \mathrm{I}$ insulin and percentage peak fluorescence. The data indicate that fluorescence flow cytometry can be used to study the distribution of insulin receptor on different cell lines and to study cells derived from patients with disease states.

Key words: Insulin receptor, flow cytometry.
A primary approach to the characterization of the insulin receptor has been through the study of its interaction with ${ }^{125}$ I-labelled insulin [1]. Those studies have yielded information about the structure of the receptor, its function, and its role in physiology and disease [2]. Insulin receptors change in number and affinity in response to a number of physiological regulators [3], may be modulated by anti-receptor antibodies [4], and are altered in a number of diseases [2]. In most of these studies, it has been impossible to obtain sufficient quantities of important target tissues for insulin action, and therefore, most studies have been performed with mononuclear leucocytes and erythrocytes [5]. In some cases, transformed lymphocytes or fibroblasts have also been employed and have been found to reflect the defect observed in freshly isolated cells [6].

In addition to insulin, it has been possible to detect and study the insulin receptors on the surface of cells using antibodies to the insulin receptor [7]. These studies have received relatively limited use in human disease [8]. In the present study, we have employed antireceptor antibodies and the technique of fluorescence flow cytometry for identification of insulin receptors and for studying their expression on different human lymphoid cèll lines.

\section{Materials and methods}

\section{Anti-sera and cultured cells}

Two sources of antibody to the insulin receptor used were: polyclonal autoantibodies to the insulin receptor derived from patients with the
Type B syndrome of insulin resistance, and a monoclonal antibody raised to insulin receptors purified from human placenta and grown as ascites tumours in mice (kindly provided by S. Jacobs). Fluorescein conjugated goat anti-human IgG or mouse IgG were purchased from Cappel Laboratories, Cochranville, Pennsylvania, USA.

IM-9 cells are a human lymphoblastoid cell line which has been extensively studied in terms of insulin receptors. Other human $\beta$-cell lines were obtained by transformation of peripheral blood mononuclear cells with Epstein-Barr (EB) virus [6]. The EB virus transformed lines are designated as EBVT and the description of their origin is given in Table 1 . All cells were grown at $37^{\circ} \mathrm{C}$ in RPMI 1640 medium supplemented with $10 \%$ fetal calf serum.

${ }^{125} \mathrm{I}$-insulin binding to the lymphoid cells was measured at $15^{\circ} \mathrm{C}$ using a tracer size of $0.1 \mathrm{ng} / \mathrm{ml}$, as previously described [6].

\section{Fluorescence flow cytometry}

Cultured cells were washed twice in cold serum-free medium. The cell pellet was resuspended in cold RPMI medium plus $1 \%$ bovine serum albumin to a concentration of $24 \times 10^{7}$ cells $/ \mathrm{ml}$. Cells $\left(2 \times 10^{6} / 100 \mu 1\right)$ were then incubated with anti-receptor antibody or a control antibody $\left(1: 100\right.$ dilution) for $1 \mathrm{~h}$ at $4^{\circ} \mathrm{C}$. The cells were washed twice with phosphate buffered saline at $4{ }^{\circ} \mathrm{C}$ and incubated for an additional hour at $4^{\circ} \mathrm{C}$ with a fluorescein conjugated second antibody $(1: 30$ dilution). Cells were again washed twice with phosphate buffered saline at $4^{\circ} \mathrm{C}$ and analyzed using a Coulter Epics $V$ flow cytometer (Coulter Electronics, Hialeah, Florida, USA). Cells $\left(10-25 \times 10^{3}\right.$ per run) were analyzed by $\log$ integral green fluorescence.

\section{Results}

The fluorescence intensity distribution of insulin receptors on four human lymphoblastoid cell lines was determined by incubating the cells with monoclonal anti- 
Table 1. ${ }^{125}$ I-insulin binding and anti-receptor antibody binding to different human lymphoid cell lines

\begin{tabular}{|c|c|c|c|c|}
\hline \multirow[t]{2}{*}{ Cell line } & \multirow[t]{2}{*}{ Patient type } & \multirow[t]{2}{*}{$\begin{array}{l}{ }^{125} \text { I-insulin } \\
\text { binding } \\
(\%)\end{array}$} & \multicolumn{2}{|c|}{$\begin{array}{l}\text { Peak fluorescence } \\
\text { Anti-receptor } \\
\text { antibody }\end{array}$} \\
\hline & & & $\begin{array}{l}\text { Poly- } \\
\text { clonal } \\
(\%)\end{array}$ & $\begin{array}{l}\text { Mono- } \\
\text { clonal } \\
(\%)\end{array}$ \\
\hline IM-9 & Multiple myeloma & 100 & 100 & 100 \\
\hline EBVT-1 & Normal female & 78 & 62 & 48 \\
\hline EBVT-2 & $\begin{array}{l}\text { Diabetic insulin } \\
\text { resistant female }\end{array}$ & 22 & 40 & 27 \\
\hline EBVT-3 & $\begin{array}{l}\text { Rabson } \\
\text { Mendenhall } \\
\text { syndrome }\end{array}$ & 2 & 20 & 0 \\
\hline EBVT-4 & $\begin{array}{l}\text { Type A extreme } \\
\text { insulin resistance }\end{array}$ & 9 & 7 & 0 \\
\hline EBVT-5 & Leprechaun (Ark-1) & 8 & 4 & 1 \\
\hline EBVT-6 & $\begin{array}{l}\text { Father of } \\
\text { leprechaun (Ark-1) }\end{array}$ & 8 & 24 & 17 \\
\hline EBVT-7 & $\begin{array}{l}\text { Mother of } \\
\text { leprechaun (Ark-1) }\end{array}$ & 65 & 46 & 46 \\
\hline EBVT-8 & $\begin{array}{l}\text { Mother of } \\
\text { leprechaun } \\
\text { (Minn-1) }\end{array}$ & 8 & 22 & 15 \\
\hline
\end{tabular}

body to the insulin receptor or a control antibody and analyzed using the flow cytometer (Fig. 1). Monoclonal anti-receptor antibody specifically labelled insulin receptors on IM-9 cells with mean peak fluorescence that was at least 60 fluorescent units over the peak of the control antibody. A similar pattern was seen using a human polyclonal anti-receptor antiserum (data not shown). Fluorescence analysis was then conducted using three different EB virus transformed cell lines which were known to represent a range of insulin binding. EBVT-1 cells derived from a normal female had $48 \%-62 \%$ of the peak fluorescence exhibited by IM-9 cells, EBVT-2 cells from an insulin-resistant diabetic female had $27 \%$ of the maximal fluorescence, and EBVT-3 cells from a patient with Rabson Mendenhall syndrome exhibited almost no specific fluorescence with monoclonal antibody. In each case, there was a close correlation between ${ }^{125} \mathrm{I}$-insulin binding and maximal peak fluorescence (Table 1). When the human polyclonal anti-receptor serum was used, a similar pattern was seen; however, with the EBVT-2 and EBVT-3 cell lines, the polyclonal antibody showed relatively higher binding than the monoclonal antibody (Table 1), suggesting that this serum might contain antibodies other than the anti-insulin receptor antibodies which bind to human lymphocytes.

Using this technique, a more extensive evaluation of other transformed lymphocytes was performed (Table 1). Cells from a patient with leprechaunism (EBVT-5) and from a patient with the type A syndrome of insulin resistance and acanthosis (EBVT-4) exhibited almost no specific fluorescence with the monoclonal

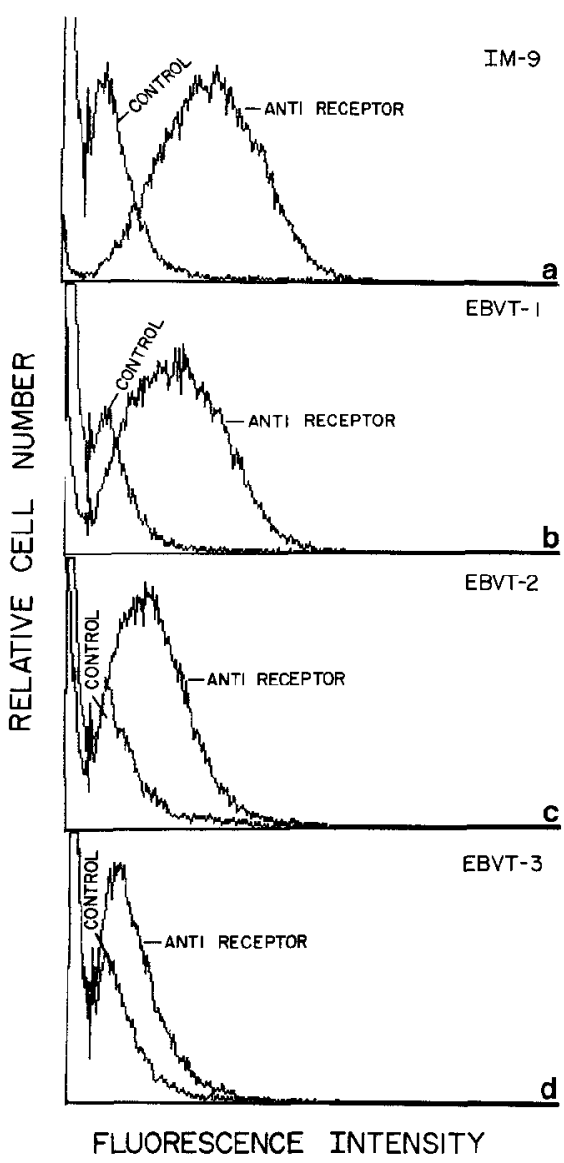

Fig. 1. Immunofluorescence analysis of the insulin receptor on human lymphoid cell lines. Cultured cells $\left(2 \times 10^{6}\right.$ cells $/ 100$ ul) were stained for flow cytometric analysis as described in Materials and Methods. Panel a shows fluorescence histograms of IM-9 cells incubated with either a control antibody (P3) or monoclonal anti-receptor antibody. Panels $b-d$ represent fluorescence histograms of the EBVT cell lines incubated with either P3 or monoclonal anti-receptor antibody

anti-receptor antibody and a very low binding of ${ }^{125}$ I-insulin or polyclonal anti-receptor antibody. Cells from the parents of two different patients with leprechaunism [Arkansas 1 (Ark-1) and Minnesota 1 (Minn-1)] showed a wide range variation, with one parent of each pair showing markedly reduced receptor content by this technique. In all cases, there was a good correlation between the monoclonal binding and insulin binding and fluorescence analysis revealed a single peak of cells.

\section{Discussion}

Autoimmune [7] and monoclonal $[9,10]$ antibodies to insulin receptors have provided useful tools for purifying the insulin receptor and determining several of its properties. Human autoantibodies to the receptor inhibit insulin binding, mimick many of the actions of insulin and immunoprecipitate solubilized insulin receptors [11]. The monoclonal antibodies immunoprecipitate insulin receptor, but do not inhibit insulin binding, suggesting that these antibodies interact with the receptor at a site distinct from the insulin binding site. 
In this study, we have characterized the distribution of insulin receptors on human lymphocyte cell lines and studied their expression using anti-receptor antibodies and flow cytometry. Our studies employed IM-9 cells as a model system because much of our knowledge regarding the insulin receptor was initially derived from studies of these cells [12]. Both the monoclonal and polyclonal anti-receptor antibody specifically labelled insulin receptors on these cells, with the monoclonal antibody showing the highest specific labelling.

Cells derived from patients with different receptor numbers demonstrated immunofluorescent labelling of insulin receptors. Three cell lines derived from patients with genetic defects in the insulin receptor (EBVT-3, 4, and 5) showed virtually no antibody binding and no ${ }^{125} \mathrm{I}$-insulin binding. In addition, the father of leprechaun (Ark-1; EBVT-6) and the mother of leprechaun (Minn-1; EBVT-8) showed markedly reduced binding of anti-receptor antibodies and ${ }^{125} \mathrm{I}$-insulin. In some cases, the binding in parents was as low as that observed in the patients, suggesting that the parent may exhibit a receptor defect which has been inherited by their child. In all cases, there was a good correlation between insulin binding and fluorescence labelling.

One feature of the insulin receptor that can be uniquely studied using the immunofluorescence technique is the question whether cell lines have a uniform distribution of receptors or may be bimodal, i.e., containing cells with a low number of receptors or some with a normal or high number of receptors. Since fluorescence is analyzed individually for each cell, it was possible to see that all cells have a proportionally high, medium, or low number of receptors depending on the line.

EB virus transformed lymphocytes have provided a useful tool for the study of human cells in culture and have been used previously to study insulin expression [13]. Since these cells grow in suspension, they provide an ideal cell type for flow cytometry analysis. However, certain caveats with regard to these cells need to be considered. First, EB virus transforms only a small percentage of lymphocytes. Thus, differences in receptor expression may reflect the genetics of transformation, the genetics of insulin receptor expression, or both. Not surprisingly, transformed lymphocytes from normal individuals exhibit a rather wide range of ${ }^{125}$ I-insulin binding which may be a result of these genetic variations or even a result of the transformation process itself. With regard to the latter point, however, comparative studies measuring ${ }^{125} \mathrm{I}$-insulin binding in cultured lymphocytes and circulating blood cells from the same individuals have revealed a close correlation [7], suggesting that transformation does not change the expression of the insulin receptor and reflects the picture seen in vivo.

In conclusion, insulin receptor expression can be studied quantitatively using fluorescence flow cytometry. The experiments described in this study indicate that different populations of human lymphocytes express different levels of immunoreactive insulin receptor on their surface. These studies suggest that flow cytometry is a useful tool in the study of insulin receptors and their expression in hyper- and hypoglycaemic syndromes in man.

\section{References}

1. Freychet $P$, Roth $\mathbf{J}$, Neville DM (1971) Insulin receptors in liver specific binding of ${ }^{125}$ I-insulin to plasma membranes and its relation to bioactivity. Proc Natl Acad Sci USA 68: 1833-1837

2. Bar RS, Harrison LC, Muggeo M, Gorden P, Kahn CR, Roth J (1979) Regulation of insulin receptor in normal and abnormal physiology in humans. Adv Intern Med 24: 23-46

3. Blackard WG, Guzelian PS, Small ME (1978) Down-regulation of insulin receptors in primary culture of adult rat hepatocytes in monolayer. Endocrinology 103: 548-553

4. Taylor SI, Marcus-Samuels B (1984) Anti-receptor antibodies mimic the effect of insulin to down-regulate insulin receptor in cultured human lymphoblastoid (IM-9) cells. J Clin Endocrinol Metab 58 (in press)

5. Schwartz RH, Bianco AR, Handwerger BS, Kahn CR (1975) Demonstration that monocytes rather than lymphocytes are the insulin binding cells in preparations of human peripheral mononuclear leukocytes: Implications for studies of insulin-resistant states in man. Proc Natl Acad Sci USA 72: 474-478

6. Taylor SI, Underhill LH, Hedo JA, Roth J, Serrano RM, Blizzard RM (1983) Decreased insulin binding to cultured cells from a patient with the Rabson-Mendenhall syndrome. Dichotomy between studies with cultured lymphocytes and cultured fibroblasts. J Clin Endocrinol Metab 56: 856-861

7. Flier JS, Kahn CR, Roth J, Bar RS (1975) Antibodies that impair insulin receptor binding in an unusual diabetic syndrome with severe insulin resistance. Science 190: 63-65

8. Jarrett DB, Roth J, Kahn CR, Flier JS (1976) Direct method for detection and characterization of cell surface receptors for insulin by means of ${ }^{125}$ I-labeled autoantibodies against the insulin receptor. Proc Natl Acad Sci USA 73: 4115-4119

9. Kull FC, Jacobs S, Su YF, Cuatrecasas P (1982) A monoclonal antibody to human insulin receptor. Biochem Biophys Res Commun 106: 1019-1026

10. Roth RA, Cassell DJ, Wong KY, Maddux BA, Goldfine ID (1982) Monoclonal antibodies to the human insulin receptor block insulin binding and inhibit insulin action. Proc Natl Acad Sci USA 79: 7312-7316

11. Kasuga M, Hedo JA, Yamada KR, Kahn CR (1982) The structure of the insulin receptor and its subunits. Evidence for multiple non-reduced forms and a $210 \mathrm{~K}$ precursor. J Biol Chem 257: 10392-10399

12. Kasuga M, Kahn CR, Hedo JA, Van Obberghen E, Yamada KM (1978) Insulin induced receptor loss in cultured human lymphocytes is due to accelerated receptor degradation. Proc Natl Acad Sci USA 78: 6917-6921

13. Taylor SI, Leventhal S (1983) Defect in cooperativity in insulin receptors from a patient with a congenital form of extreme insulin resistance. J Clin Invest 71: 1676-1685

Dr. R. Maron

Joslin Diabetes Center

1 Joslin Place

Boston, Mass 02215

USA 